\title{
A Mithras-misztériumok és a kereszténység kapcsolatai a pannoniai provinciákban a Kr. u. 3-4. században
}

\author{
Connections between the Mysteries of Mithras and Christianity \\ in the Pannonian Provinces in the $3^{\text {rd }}-4^{\text {th }}$ Centuries A.D.
}

The study of the connections between the Mithras mysteries and Christianity in the Central Danube region in the $3^{\text {rd }}-4^{\text {th }}$ centuries has not attracted many researchers of classical archeology and antique religion in recent times. The revision of the most relevant written and archaeological sources, as well as of their interpretation problems, may contribute to the better understanding of the Mithraic-Christian relations in the region. This attempt regards the most important results of the Hungarian Mithraic research of recent years and on István Tóth’s Pannonian religious history published in 2015.

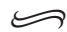

A Mithras-misztériumok és a kereszténység kapcsolatrendszerének kutatása a Közép-Duna-vidéken a 4. században nem vonzotta az utóbbi időben az ókori régészet és az antik vallástörténet kutatóit. A legrelevánsabb írott és régészeti források, valamint értelmezési problémáik bemutatása talán jobban elöremozdítja a mithraikus-keresztény kapcsolatok jobb megismerését a vizsgált térségben, különös tekintettel az utóbbi évek magyar Mithras-kutatásának legfontosabb eredményeire és Tóth István 2015-ben megjelent pannoniai vallástörténetére. ${ }^{1}$

Poetovio, a publicum portorium Illyrici gazdasági központjának vallási élete öt feltárt mithraeummal inspiráló helyszín volt Tóth István számára. Elmélete szerint egy kiemelkedő müveltségü, sokat utazó, több vallást, filozófiai rendszert és asztrológiai összefüggéseket is jól ismerő személy alapíthatta a Mithras-misztériumokat 
Poetovióban a 2. század elején, iranizáló elemekkel téve egzotikussá tanításait. ${ }^{2}$ Ez a feltételezett alapító szervezte meg Tóth István szerint a Mithras hívők új hálózatát, amely Poetovióból Italia, Nyugat-Európa és a Balkán irányába terjedt tovább. ${ }^{3}$ Tóth István M. Gongius Aquileiensis és Florentius pater poetiviói IV. számú mithraeum közelében 1970-ben előkerült, december 24-én kelt dedikációs feliratára ${ }^{4}$ és Victorinus kronológiai töredékére ${ }^{5}$ különös elméletet alapozott.

Mithras hívei, mindenekelőtt a III. mithraeumot Gallienus császár idején megépíttető daciai legiók vezérkara által ünnepélyes körülmények között megünnepelt téli napforduló (Sol Invictus Mithras születésnapja) hatással lett volna a Victorinus püspök által vezetett kortárs keresztény közösségre, akik ugyancsak ekkor ünnepelték Poetovióban a karácsonyt, Krisztus születésnapját a téli napforduló idején, illetve az azt megelőző napon (december 24-25-én). ${ }^{6}$

Ezt a pogányok ${ }^{7}$ és keresztények között nagyfokú vallási toleranciát, ökumenikus összeborulást, kulturális kölcsönhatásokból felépített vallási-kulturális transzfert feltételező elképzelést egy olyan multikulturális római városban, mint Poetovio, minden bizonnyal örömmel fogadják majd akár a misztériumvallások és a kereszténység közötti hasonlóságokat, ${ }^{8}$ akár a vallási akkulturációt hirdető elméletek hívei. Victorinus kronológiai töredékét azonban nem a Mithras-misztériumok Sol Invictus-születésnapi bulijai inspirálták, hanem egy 2. századi kis-ázsiai (kappa-

2 Tóth 2003. 7-18.; Tóth 2015. 169-176. A nemzetközi kutatásban Roger Beck elmélete nyomán elterjedtebb, de csak közvetett érvekkel megtámogatható narratíva a Mithras-misztériumok Róma városi kialakulásáról egy Kis-Ázsiából, Kommegénéből, esetleg Kilikiából Rómába érkező, a vallás egzotikus-orientalizáló „másságát” hangsúlyozó alapítóval: Beck 1988. 115-128.; Bowden 2010. 194-196.; Versluys 2013. 248-250.; Bremmer 2014. 128-129.; Mastrocinque 2017. 27-28., 82-83., 238., 327-330.

3 Tóth 2003, 11-18., 31-35.

4 „M(arcus) Gong(ius)/Aquilei/ensis pro /salute/ sua souor/um(que) om/nium v(otum) s(olvit) l(ibens) $\mathrm{m}$ (erito)/ d(e)d(icavit)[vagy d(edit) d(edicavit) vagy d(ono) d(edit)] VIIII K(alendas) Ian(uarias)/ p(osuit) p(ater) p(ientissmus) Florentius" - ILJug 1978. 192, Kat. Nr. 1150.; Tóth 1988. 23., Kat. Nr. 18.; Tóth 2004. 237-238. Iva Curk 1957-ben kelt ásatási jelentésének vallástörténeti szempontú értékelése a IV. számú mithraeum topográfiai kontextusának bemutatásával: Selem 1980. 140-143.

5 „VIII. Kal. Ian. natus est dominus noster Iesus Christus” - Vict. Poet. Frg. Chron. (ed. Dulaey 1993.)

6 Tóth 2004. 237-241. A poetoviói Victorinus által vezetett közösség életére vonatkozó, alapvetően Victorinus fennmaradt egzegetikai műveiből kikövetkeztetett adatokat összegyűjtötte Bratož 2002. 7-20.

7 A késő antik vallástörténet terminológiai vitáinak kereszttüzében (Jürgasch 2016. 115-138.; Nagy 2016c. 121-132.) újabban problematikussá vált „pogány” kifejezést a továbbiakban „nem keresztény" értelemben használom.

8 Ehhez kritikusan 1. Nagy 2007. 101-119.; Bremmer 2014. 142-165., további forrásokkal és irodalommal. 
dokiai), a 3. század eleje óta Róma városában is ismert keresztény hagyomány. ${ }^{9}$ A Mithras-misztériumok ikonográfiájával foglalkozó kutatás ma már problémásnak tartja Mithras sziklából születésének időzítését is a téli napforduló idejére, mert a sziklából születés ábrázolásai egyértelmü kapcsolatot mutatnak a zodiákus nyári csillagképeivel és paranatellonjaival. ${ }^{10}$ Emellett Sol Invictus december 25-én kocsiversenyekkel megrendezett ünnepére vonatkozóan a 354. évi Róma városi codex-kalendáriumot megelőzően nincsenek egyértelmű adatok, ${ }^{11}$ ráadásul a poetoviói dedikáción szereplő dátum kivételével a december 24-e eleve nem jellemző a Mithras-hívek által állított feliratokon. ${ }^{12}$

Martin Wallraff részletes kutatásai, forrásvizsgálatai nyomán Sol Invictus kultuszának kapcsolata a korai kereszténységgel mindenekelőtt Nagy Konstantin vallási politikájának köszönhetö. ${ }^{13} \mathrm{~A}$ négy (illetve öt) koszorús kőfaragó, a pannoniai IV sancti coronati szenvedéstörténete sem bizonyítja Sol és Krisztus azonosságát a keresztények számára: a történet szerint a monumentális fehérmárvány Sol szobrot azért voltak hajlandók megfaragni a keresztény kőfaragók egy Diocletianus által alapított képzeletbeli (?) templom számára, mert isten teremtményeit, a napot (az igazságosság napját), csakúgy, mint az állatokat szívesen ábrázolták, csak istenekként nem imádták őket. ${ }^{14}$ Mindenesetre a poetiviói IV. mithraeumhoz kapcsolódóan ismertté vált Aurelius Iustinianus dux labefactatum építési felirata (CIL III 4039), amely a tetrarchia idején egy mithraeum újjáépítéséről tanúskodik. ${ }^{15}$ A szenvedéstörténet maga egy nemrégiben elvégzett elemzés szerint egy ismeretlen pannoniai keresztény közösség kulturális emlékezetének terméke, akik szívesen dicsérik Istent teremtményein keresztül, de nem hajlandók imádni a teremtményt a teremtő helyett. ${ }^{16}$

Elhagyva Poetoviót, amely a 4. században, legkésőbb Nagy Konstantin uralkodása idején már Noricumhoz tartozott, ${ }^{17}$ Mithras utolsó nagy sikere Pannoniában a carnuntumi III. mithraeum másodlagosan felhasznált oltárán érhető tetten, amelyen a 308-ban megrendezett carnuntumi császártalálkozó résztvevőinek dediká-

9 Dulaey 1993. I., 38. További forrásokkal; Nagy 2012a. 134-135.

10 László-Nagy-Szabó 2005. 179-183.; Nagy 2012b. 42-46., 50-51.

11 Rüpke 2006. 79., 81., további szakirodalommal, nem zárva ki azt a lehetőséget sem, hogy a december 25-ei bejegyzés későbbi betoldás.

12 Wallraff 2001. 174-180.; Nagy 2012a. 134-135. A szoláris krisztológia különféle kérdéseit jól összefoglalja Wallraff 2001. 44-88.

13 Wallraff 2001. 144-151., 174-180.

14 Passio IV sanct. cor. 1-3 (ed. Delehaye 1910. 765-779.); Nagy 2012a. 109-110., 120., 147-148.

15 Selem 1980. 141.; CIL III. 4039.; CIMRM II. 1614.; Kovács 2011. 145., a felirat szövegével: „Templum dei Sol(is) Inv(icti) Mit(hrae)/ Aur(elius) Iusti/nianus v(ir) p(erfectissimus) dux labefa/ctatum re/stituit."

16 Nagy L 2012a. 20-21., 119-152.

17 Fitz 1994. 1183.; Nagy 2012a. 140-141., további forrásokkal. 
ciója olvasható. ${ }^{18}$ Hogyan rekonstruálhatók Mithras további esetleges sikerei vagy éppen kudarcai a vizsgált térségben a konstantini fordulat után?

A közös egyéni és csoportidentitással bíró Mithras-hívők szociális-vallási kapcsolati hálóinak újabban divatos vizsgálatai feliratok segítségével ${ }^{19}$ a 4 . században már nem lehetségesek, mert a korábban oltárokat állító hívők vallási attitüdje megváltozott: a tetrarchia időszakát követően, legkésőbb Nagy Konstantin idején a többi istenhez hasonlóan ${ }^{20}$ eltünnek a Mithras-dedikációk a pannoniai provinciákból. ${ }^{21}$ Figyelembe véve a felirat-állítási szokások 3. század második felétől kezdve birodalomszerte csökkenő tendenciáját is, ${ }^{22}$ a votív feliratok pannoniai megszünését aligha lehet kizárólag pszichológiai okokkal magyarázni, mint ahogy azt Ramsey McMullen és őt követve Eberhard Sauer gondolta: a felirat-állíttatók már nem akarták, hogy hosszú időn keresztül olvassa az utókor az üzeneteiket, mert kétségessé vált volna számukra az őket körülvevő jól megszokott világ hosszú távú fennmaradása és fontossága. ${ }^{23} \mathrm{~A}$ hivatalos feliratok és sírfeliratok - egyre csökkenő tendenciát mutatva ugyan - de továbbra is jól adatolhatók a 4. századi pannoniai provinciákban. ${ }^{24} \mathrm{~A}$ votív felirat-állítás abbamaradásának lehetséges okait későbbi kutatási feladatként a pannoniai provinciák krisztianizációja mint történeti folyamat részletes vizsgálata keretein belül érdemes feltárni: a kereszténység terjedése, a keresztény császárok valláspolitikájában beállt fordulat, vagy a hagyományos kultuszgyakorlat divatjának állami valláspolitikai kontrolltól független megszünése áll a folyamat hátterében? ${ }^{25}$

Sikeresnek látszik Italiában, például Rómában vagy Ostiában egy másik vizsgálati módszer, ${ }^{26}$ amely egy komplex késő antik vallási topográfia megírását tűzi ki céljául a régészeti adatok szisztematikus összegyüjtését követően. Ez az írott források, feliratok hiányában is alkalmazható módszer a pannoniai provinciákban is müködhetne. A probléma azonban az, hogy több mithraeum feltárására régi ásatási mód-

18 CIMRM II. 1697-1698.; Kat. Carnuntum 2011. 167., Kat. Nr. 34.; Kat. Carnuntum 2014. 224225., Kat. Nr. 509. a felirat szövegével: „D(eo) S(oli) I(nvicto) M(ithrae)/ fautori imperii sui/ Iovii et Herculii/ religiosissimi/ Augusti et Caesares/ sacrarium/ restituerunt"; Tóth 2015. 181-182.

19 Rüpke 2013. 261-277.; Szabó 2013. 43-72.; Szabó 2017. 155-158.

20 A carnuntumi Pfaffenberg Iuppiter Optimus Maximus K(arnuntinus) szentélykörzetében az utolsó biztosan datálható votív felirat 313-ra keltezhető (bár a meglehetősen töredékes feliratokat publikáló Ioan Piso szerint egyes töredékek a kultusztevékenység 313 utáni folytatására is utalhatnak), Sirmiumban az utolsó votív dedikáció 326-ra keltezhető: Piso 2003. 14-15.; Kovács 2004. 188-189.

21 Kovács 2004. 188-189.

22 McMullan 1982. 233-246.

23 McMullan 1982. 233-246.; Sauer 1996. 74.

24 Kovács 2004. 185-195.; Bevelacqua 2014. 75-111.

25 Nagy 2018b.

26 Bjørnebye 2016. 197-212., további irodalommal. 
szerekkel történt meg még a II. világháború előtt, és éppen a szentélyek legutolsó, 4. századi használati idejéről tudunk a legkevesebbet az ásatási jelentésekből. ${ }^{27}$

Mindazonáltal talán mégis megpróbálható a kultusztevékenység utolsó időszakának és befejezésének rekonstruálása a szentélyek stratigráfiája alapján (ha volt ilyen) és a késő római leletanyag vizsgálata alapján (ha rendelkezésre áll ilyen anyag). Mindezek mellett, vagy ezeken kívül csupán közvetett támpontot jelent a mithraeumok 4. századi történetének megírásában a krisztianizáció történelmi folyamatába beillesztett császári rendelet-sorozat a „babonás” pogány kultuszok ellen egészen Nagy Theodosius minden kultuszt, áldozatbemutatást betiltó rendeletéig, ennek ellenére hajlamosak vagyunk akár az ásatásokon dokumentált szentélyrombolásokat, akár a kultusz befejezését hozzákeltezni e rendeletek évszámaihoz, különösen, ha a feltárásokon talált érmek is alátámasztani látszanak a pogányellenes rendeletekhez hozzárendelt keltezéseket. ${ }^{28}$

Új ásatási eredmények segíthetik a késő antik pannoniai provinciák mithraikus vallási életének rekonstruálását: a két oltárral és falfestmény töredékekkel adatolt savariai mithraeum leletanyaga fontos lehet a szentély kronológiájának megállapításához. Kiss Péter 2014-ben publikált ásatási jelentésében még nincs szó kronológiáról, ${ }^{29}$ de 2016-ban, a tarquiniai Mithras-konferencián bemutatott előadásában már lehetett hallani a szentély 4. századi használatáról az ott talált leletanyag alapján. ${ }^{30}$ Ezzel szemben a Müller Róbert által 1994-ben, 2001-ben és 2003-ban kutatott Hévíz-egregyi római épület 3. századi kőperiódusához tartozó mithraeumot az épület pusztulása után, a 4. századi kőperiódusban már nem állították helyre. ${ }^{31}$ Hasonlóan nem müködött már a késő római korban az aquincumi legióstábor tribunus laticlavius házának Kocsis László által 1979-1980-ban feltárt mithraeuma, amelynek oltárait a szentély északi részére áthelyezve még a 4 . századot megelőzően elfalazták. ${ }^{32}$

Mojca Vomer Gojkovič a poetovioi II. mithraeaum használatának végét a 4. század közepére keltezi a mithraeumhoz tartozó kútból előkerült érmek alapján. ${ }^{33}$ Nagy Konstantin és családtagjainak korára keltezett érmek alapján a Gallienus idején berendezett III. számú mithraeum is müködhetett még a 4. század első felében. ${ }^{34} \mathrm{Az}$ érmek azonban csak az épületek 4. századi használatát igazolják, a

27 Aquincum esetében 1. Topál 2001. 269-272.; Zsidi 2011. 20-25. Fertörákos esetében Tóth 1971. 214-226.; 322-334. Sárkeszi esetében Fitz 1957. Poetovio esetében Vomer-Gojković 2001. 105124.

28 Nicholson 1995. 358-362.; Sauer 1996; Hahn et alii 2008; Lavan-Mulyran 2011., további irodalommal; Hahn 2015. 115-140.

29 Kiss 2014. 27-32.

30 Kiss 2016.

31 Müller 2004. 11-12.

32 Kocsis 1991. 152.

33 Vomer-Gojkovič 2001. 113.

34 Selem 1980. 140. 
4. századi kultuszra vonatkozóan nem szolgáltatnak adatokat. Csak közvetett bizonyíték a poetiviói IV. számú mithraum 4. századi müködésére az a körülmény, hogy a 3. század végén, legkorábban Diocletianus idején építtette újjá Aurelius Iustinianus. ${ }^{35}$ Hasonló a helyzet Carnuntumban is, ahol az osztrák kutatás az I. számú mithraeum használatával a 4. század közepét követő időszakig számol, egy Eduard von Sacken régi ásatásából származó Constans érem alapján. ${ }^{36}$ Mathilde Grünewald egy 4. századi mázas dörzstáltöredéket publikált a 308-ban újjáépített carnuntumi III. számú mithraeum elöteréből is. ${ }^{37}$

Nagy Tibor rövid ásatási jelentései nyomán sokáig a 4. század végéig számolt kultukus tevékenységgel az aquincumi Symphorus mithraeumban. ${ }^{38}$ Az aquincumi polgárváros legújabb régészeti kutatásai nyomán egyre inkább úgy tünik, hogy a 4. század legnagyobb részében a polgárvárost (legalábbis annak keleti részét) már nem lakták, Lassányi Gábor és Láng Orsolya a korábban 4. századra datált leleteket alaposabban megvizsgálva a 3. század második felére - végére keltezték vissza. ${ }^{39}$ A sárkeszi mithraeum 1932-1933-ban készült ásatási jelentéseit (Marosi Arnold, Dormuth Árpád) értelmező Nagy Tibor és Fitz Jenő a szentély szándékos felhagyása mellett érveltek Pannonián kívüli írott források nyomán kikövetkeztetett 4. századi pogány-keresztény konfliktusokra hivatkozva, mert a hívek egy gödörbe rejtették el a szentély bejáratánál a kultuszképet a szentélyben álló oltárokkal és mécsessel együtt. ${ }^{40}$ A szentély felszerelésének deponálása azonban jól datálható leletek segítségével nem keltezhetö.

Járdányi-Paulovics István a camponai erődtől északra előkerült mithraeum 1935-ben kelt ásatási jelentésében nem figyelt meg szándékos szentélyrombolást, „képrombolásról” csak a kultuszkép esetében ír, amelyet eredeti helyéről elmozdítva és ezáltal megrongálva később másodlagosan használhattak fel (a relief mindenesetre nincs apró darabokra törve). ${ }^{41}$ A szentély használatának végét datáló leletek hiányában nem tudta keltezni, a lelőhelyen talált kerámiatöredékekkel nem foglalkozott. ${ }^{42}$ Hasonlóképpen nem ismert az építkezés során (nem régész jelenlétében) előkerült brigetiói mithraeum végső pusztulásának időpontja sem, csupán a szentély padlóján összedobált kőemlékekről és a padlón megtalált, Magyar Nemzeti Múzeumba ke-

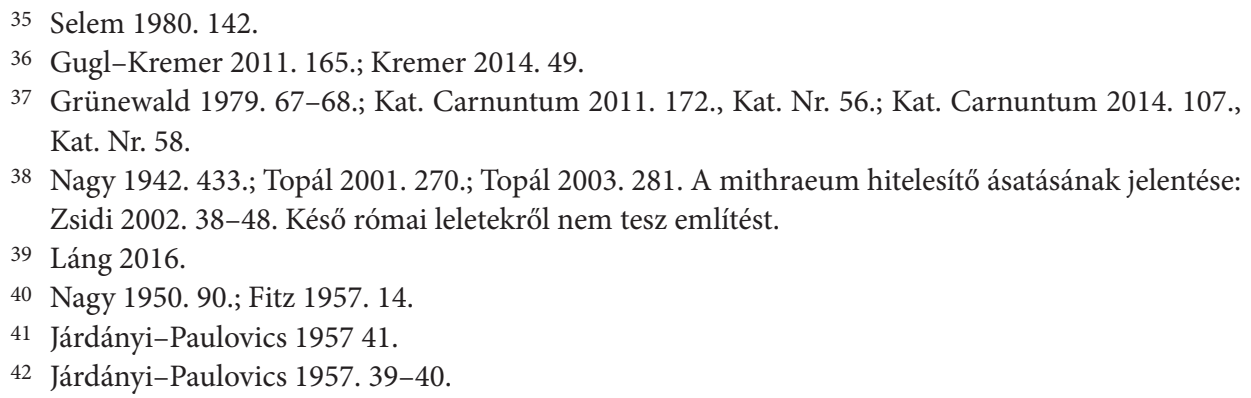


rült taurochthonia-reliefes bronztábláról és néhány feliratos oltárról van említés. ${ }^{43} \mathrm{~A}$ 2002-2003. évi nagy felületű feltárások során jól megismert budaörsi római vicus és temető késő római periódusa jól adatolt, ennek ellenére a „szőlőhegyen” 1821-ben megbolygatott mithraum 4. századi használatára semmilyen bizonyíték nincs. ${ }^{44}$

A fertőrákosi mithraeum 4. századi müködése sem a régi (Storno Ferenc), sem az újabb (Gabrieli Gabriella) ásatási megfigyelések alapján nem rekonstruálható: az első ásatási jelentésben szereplő, idővel elveszett 4. századi érmek a már a 4. századot megelőzően felhagyott mithraeumban létesített utólagos hamvasztásos temetkezésekből származnak, az 1990-1991-ben elvégzett ásatások során talált 4. századi érmek az 1866. évi ásatás kidobott földjében kerültek elő újkori leletekkel együtt. ${ }^{45}$

Italiából és - Britannia kivételével - a nyugati provinciákból vannak részben feliratos, részben éremdatált, részben stratigráfiai adatok 4. század végéig, sőt az 5. század elejéig folyamatosan használt mithraeumokról. ${ }^{46}$ Hiányosabb pannoniai adataink alapján azonban ez a kontinuitás legfeljebb a 4. század első feléig, középső harmadáig követhető, nem feltétlenül a század végéig, összhangban a votív feliratok Nagy Konstantin-korabeli eltünésével. A szentélyek sok esetben publikálatlan, vagy csak részben publikált 4. századi leletanyagának szisztematikus, esetleg pontosabb keltezésekre irányuló vizsgálata, amelyekre érdemes lenne későbbi kutatási projekteket indítani, sokat módosíthat ezen a képen.

A Mithras-misztériumok és kereszténység között feltételezett kulturális kölcsönhatások másik forráscsoportja lehettek volna a mitológiai és bibliai jelenetekkel díszített ládikavereteken ${ }^{47}$ előforduló mithraikusnak mondott szimbólumok. A két intercisai, valamint egy császári ládikavereten is látható apró állatalakokat (méh, hoszszú nyakú madár, delfin, kígyó) csillagot, jobb kezek kézfogását (dextrarum iunctio) Gáspár Dorottya a pannoniai Mithras-kultuszra jellemző szimbólumoknak tartotta, amelyek a ládikák keresztény tulajdonosait is inspirálták volna, ${ }^{48}$ hivatkozva a Römisch-Germansiches Zentralmuseumban, Mainzban örzött intercisai ládika ábrázolásait elemző Erika Dinkler-von Schubert korábbi véleményére. ${ }^{49} \mathrm{Az}$ apró állatalakok, csillag és dextrarum iunctio (a német szakirodalomban Zwickelmotive) újabb

43 Radnóti 1946-1948. 137-138.; Barkóczi 1951. 8., 34., 48. Nincs adat arra, hogy a mithraeum a 4. században müködött volna, amikor a legiós tábor körül, a katonaváros egykori területén már temetkeztek: Barkóczi 1951. 9.

44 Összefoglalóan: Ottományi et alii 2014. 46-49., 63-68.; 85-89.

45 CIMRM II. 1636.; Vermaseren 1963. 166.; Tóth 1971. 221-223., 326., 330-331.; Gabrieli 1996. $155-156$.

46 Clauss 1986. 279., 283.; Nicholson 1995. 358-362.; Sauer 1996. 51-72.; László-Nagy-Szabó 2005. 133-173; Bjørnebye 2016. 198-199., 205-210.; Mastrocinque 2017. 313-320., a késő antik források és feliratok legújabb összefoglalásával.

47 Nagy 2012c. 61-90.; Nagy 2016b. 382-394.; Nagy 2016c. 121-132.

48 Gáspár 2002. 38-39.

49 Dinkler-von Schubert 1980. 145. 
elemzése azonban cáfolta, hogy ezek az ábrázolások pogány-keresztény kapcsolatokat igazoló mithraikus szimbólumok lennének. ${ }^{50}$ Ezek az alakok annyira elterjedtek a római művészetben, hogy aligha lehetnek kifejezetten a 4. századi mithraikus-keresztény kulturális kölcsönhatások bizonyítékai: a dextrarum iunctio például a házasság szimbólumaként akár privát, keresztény kontextusban is elöfordulhat. ${ }^{51}$

Egy 1894-ben Zámolyból előkerült publikálatlan késő római szarkofág Diocletianus éremmel és a 4. század első felére keltezett hagymafejes fibulával fából készült lemeztöredéket tartalmazott az egyik oldalán Sol, a másik oldalán Luna mellkép ábrázolásaival, Tóth István szerint a bikaölést, valamint Mithras és Sol lakomáját ábrázoló hordozható kultuszkép két oldalához tartozó ábrázolásokat a környék utolsó Mithras papja vitte magával a sírba a 4 . században. ${ }^{52}$ Császárról és Intercisából ismerünk ugyan Sol ábrázolásaival díszített ládikavereteket (a császári 1. számú sír ládikájáról Sol és Luna ábrázolást is a hét napjait megjelenítő istenek között), ezek azonban részben álló alakok, részben quadrigát hajtanak. ${ }^{53}$ Sol és Luna mellképek formájában nem jelentkeznek a ládikavereteken, ezért nem valószínü, hogy egy fából készült ládikához tartozna a falemez. Mivel az ún. Duna-vidéki lovas isten(ek) ábrázolásain (varázsgemmákon, pannoniai ólomtáblákon) a Sol és Luna büsztök ritkán fordulnak elő és nem olyan elrendezésben, hogy a zámolyi töredékeket lovasisten-táblaként tudnánk rekonstruálni ${ }^{54}$ ikonográfiai alapon valóban nem kizárt, hogy egy kétoldalas mithraikus kultuszkép kis töredékéről van szó. ${ }^{55}$ Amennyiben a töredékesen megmaradt Sol és Luna büszt valóban egy mithraikus kultuszképhez tartozik, tükrözheti a fából készült lemez egykori tulajdonosának mithraikus vallási identitását, de mindebből még nem következik sem az, hogy papnak kellett lennie, sem az, hogy ő lett volna az utolsó Mithras-pap a 4. század első felében a környéken. Ezért a Mithras-papok, mint önálló, vallási identitással rendelkező egyéniségek írott források és feliratok hiányában továbbra is jórészt láthatatlanok maradnak Nagy Konstantin uralkodása után a 4 . századi pannoniai provinciákban.

Intercisa déli temetőjének 2000. számú sírja egy kőlapokból, köztük egy másodlagosan felhasznált (Iuppiter, Iuno, Liber, Tellus dedikációt tartalmazó) oltárból épí-

50 Nagy 2012c. 78-79.

51 Nagy 2012c. 79.

52 Tóth 2006. 3-6.

53 Császár: 1. sír: álló Sol és Luna alakok, 2. sír: quadrigás Sol medaillonban; Intercisa, délkeleti temető 1023. sír: álló Sol (tévesen Mercuriusként publikálva) és két ismeretlen kontextusú intercisai példány (quadrigás Sol medaillonban): Buschhausen 1971. Kat. Nr. A 14., 39., 65., 69., 102., Taf. A 15., 43., 82., 89., 101.; Gáspár 1986. I. Kat. Nr. 349., 350., 381., 382.; Nagy 2012c. 85; egy további publikálatlan töredék Pannoniából (quadrigás Sol medaillonban): Kat. Carnuntum 2014. 242-243., Kat. Nr. 549.

54 CMRED I. Kat. Nr. 135. (ólomtábla, hajviselet stílusa alapján tetrarchia-kori keltezéssel); Kat. Nr. 193., 194. (varázsgemmák); Pl. LXIV. LXXXVIII; CMRED II. 183.

55 L. még Vágási 2016. 100., további párhuzamokkal. 
tett sír a 4. század középső harmadából - második feléből, amelyet egy közeli Mithras szentélyből (Intercisa három feltételezett mithraeumának egyikéből) származó taurochthonia kultuszképpel fedtek le és egy Sol Invictus Heliogabalus oltárt helyeztek rá. ${ }^{56}$ Tóth István feltételezte, hogy a sírba egy egykori Mithras hívőt temettek el, és vagy ö, vagy a hozzátartozói szándékosan hozták el a kultuszképet egy akkor már használaton kívüli mithraeumból, hogy ezzel kifejezzék az elhunyt nem keresztény vallási identitását. ${ }^{57}$

Tóth Istvánnak igaza van abban, hogy a két vizsgált temetkezéshez kapcsolódó rendhagyó kontextusok szándékos pogány (pontosabban nem keresztény) vallási identitásra engedhetnének következtetni akár a halott, akár az őt eltemető közösség részéről, ${ }^{58}$ mert sem a Mithras-kultuszkép, sem a többi antik istent, isteneket ábrázoló relief (a bronz ládikaveretek kivételével) nem jellemző melléklet a késő római pannoniai temetőkben.

A poszt-processzuális régészet és az identitásrégészet számon tartja az aktív tevékenység, egyfajta hatóerő, ágencia (agency) fogalmát. ${ }^{59}$ Ennek megfelelöen a késő római temetkezési kontextusokban egyedülállóan rendhagyó mellékletadási szokások akár az elterjedtebb temetkezési-mellékletadási szokásokban kimutatható helyi társadalmi normáktól szándékosan eltérő egyéni és közösségi ágenciák megnyilvánulásai is lehetnek. A mitológiai jelenetekkel díszített késő római használati tárgyak - függetlenül attól, hogy háztartásokban, vagy sírmellékletként kerülnek-e elő - tulajdonosuk, használójuk, akár a sírba temetett halott egyéni, akár az őt eltemető közösség kollektív ágenciájaként és a 4. században még mindig fontos értéknek tekintett antik müveltség, a paideia megnyilvánulásaiként egyaránt értelmezhetők. ${ }^{60}$

Szembesülni kell azonban olyan módszertani problémákkal, amelyek gyengíteni látszanak azt a törekvést, hogy késő római régészeti kontextusokban egyértelműen azonosítsuk az írott forrásokból jól ismert, klasszikus értelemben vett hagyományos római alapértékeket (paideia, mos maiorum) mint kifejezetten pogány, akár mithrai-

56 Tóth-Visy 1985. 37-56., Abb. 1-2; Tóth 1988. 58-61., Kat. Nr. 77.; Tóth 2003. 37-68.; Kovács 1999. 39.; Visy 2016. 44-45., 68., Kat. Nr. 29., 56. A relief újpythagoreus értelmezése: Mazur 2008. 208-218. A taurochthonia elterjedtebb komplex asztrológiai alapú értelmezése a nemzetközi kutatásban: Beck 2006., a magyar kutatásban: Szabó 2012. 125-134.

57 Tóth 2015. 203.

58 A vallási identitás mint egyéni és csoportidentitás elemzésének elméleti alapjaival az ókeresztény korban narratív szövegeken, feliratokon és építészeti emlékeken keresztül foglalkozik RebillardRüpke 2015. összefoglalóan 3-27. Kísérlet az identitásrégészet módszertanának bevezetésére a hazai kora keresztény régészetben: Nagy 2018a.

59 Díaz Andreu 2005. 5-6.; Curta 2013. 168-170.; Szabó 2017. 155-156.; Koncz-Szilágyi 2017. 205., további irodalommal

60 Ehhez l. Rüpke 2013. 263; pannoniai vonatkozásban Gesztelyi 2016. 155-156. A görög mitológia (és mitológiai ábrázolások) relevanciájához a késő antik általános műveltségben általában l. Huskinson 1974. 68-97.; Cribiore 2005; Gemeinhardt 2007; Leppin 2015. 
kus vallási identitások bizonyítékait, ráadásul ezeket - mint a pogány vallásosság utolsó megnyilvánulásait - szembe állítsuk egy folyamatosan krisztianizálódó milliővel.

Jó példa erre a Komárom-Esztergom megyei Császár falu határában 1901-ben feltárt 1. számú sír, amelybe egy férfit és egy nőt temettek el. A két halott mellé mitológiai és bibliai jelenetekkel díszített ládikát helyeztek el, miközben az épített sír falait két másodlagosan felhasznált sírkőből és egy Terra Mater oltárból alakították ki. ${ }^{61}$ A sír építöi szemlátomást nem törődtek a korábbi kőemlékeken látható, olvasható tartalmakkal, a sírköveket és oltárt kizárólag építőanyagként és nem vallási identitásuk jeleként használták fel.

Összefoglalásképpen megállapítható, hogy a Mithras-misztériumok és kereszténység 3-4. századi kulturális kölcsönhatásainak vizsgálata több módszertani problémát vet fel, mint amennyit megold. Egyelöre nincsenek egyértelmü bizonyítékok a pannoniai provinciákban Mithras-hívők és keresztények közötti viszályokra, konfliktusokra, szisztematikus szentélyrombolásokra, annak ellenére, hogy gyakorlatilag csak azokban a nagyobb városokban vannak adatok mithraeumok 4. századi használatára (Poetovio, Carnuntum, Savaria) legalább a 4. század középső harmadáig, ahol keresztény közösségek is működnek. ${ }^{62} \mathrm{~A}$ korábbi kőemlékek másodlagos felhasználása a 4. század második felében (pl. az intercisai 2000. számú sír esetében), vagy a mithraikus kőemlékek szándékos elrejtése (pl. a sárkeszi mithraeum esetében) inkább a szentélyek békés felhagyására enged következtetni. Jonas Byørnebye 2016-ban, egy 4. századi pogány-keresztény kapcsolatokról szóló kötetben publikált gondolatai jól alkalmazhatók a pannoniai provinciák esetében is: „The christianisation of public life took more direct forms... mithraic cursus and communal activities would become less attractive for a variety of reasons, and the mithraea would be gradually abandoned... It is not difficult to visualise the last old pater bricking up his mithraeum, when there were no initiates left. When there are no incentives for new recruits, as was the case in fifth-century Rome, old religions fade away." ${ }^{3}$ Italiával és Rómával összehasonlítva ez a folyamat a pannoniai provinciákban a 4. század végénél és az 5. századnál mindenképpen korábban, legkésőbb a 4. század második felében kezdődött el. Ezért az a Rajko Bratož által a Közép-Duna-vidékre vonatkozó írott források alapján megfogalmazott tézis, amely szerint a térségben a 4. században alacsony fokú, gyenge krisztianizációval kellene számolnunk ${ }^{64}$ mindenképpen átértelmezésre szorul a későbbi régészeti és vallástörténeti-egyháztörténeti kutatás részéről.

61 RIU 3., Kat. Nr. 657., 658.; Nagy 2012c. 61-62.

62 Poetovio: Bratož 2002. 7-20. Carnuntum: Pülz 2014. 57-59. Savaria: Tóth 2011. 188-200.

63 Bjørnebye 2016. 210.

64 Bratož 2011. 211-213. 


\section{Felhasznált irodalom}

Alföldi et alii 1942 = Alföldi András - Nagy Lajos - László Gyula (és munkatársaik): Budapest az ókorban, 2. rész. In: Szendy Károly (szerk.): Budapest története I. Budapest, 1942. 386-463.

Barkóczi 1951 = Barkóczi László: Brigetio. Budapest, 1951. (Dissertationes Pannonicae II/22.)

Beck 1998 = Beck, Roger: The Mysteries of Mithras: A New Account of Their Genesis. Journal of Roman Studies 88. (1998), 115-128.

Beck 2006 = Beck, Roger: The Religion of the Mithras Cult in the Roman Empire: Mysteries of the Unconquered Sun. Oxford, 2006.

Bevelacqua 2014 = Bevelacqua, Gaetano: Observations on Early Christian Epigraphy in Pannonia. Studia Patristica 73. (2014), 75-111.

Bjørnebye 2016 = Bjørnebye, Jonas: Reinterpreting the Cult of Mithras. In: Salzman, Michele Renee - Sághy, Marianne - Lizzi Testa, Rita (eds.): Pagans and Christians in Late Antique Rome. Conflict, Competition, and Coexistence in the Fourth Century. Cambridge, 2016. 197-212.

Bratož 2002 = Bratož, Rajko: Der Bischof Victorinus und die Kirchengemeinde von Poetovio (2. Hälfte des 3. Jahrhunderts). Zalai Múzeum 11. (2002), 7-20.

Bratož 2011 = Bratož, Rajko: Die kirchliche Organisation in Westillyricum (vom späten 4. Jh. bis um 600). In: Heinrich-Tamáska Orsolya (szerk.): Keszthely-Fenékpusza im Kontext spätantiker Kontinuitätsforschung zwischen Noricum und Moesia. Budapest - Leipzig - Keszthely - Rahden/Westfalen, 2011. 211-248. (Castellum Pannonicum Pelsonense 2.)

Bremmer $2014=$ Bremmer, Jan N.: Initiaton into the Mysteries of the Ancient World.

Berlin - Boston, 2014. (Münchner Vorlesungen zu Antiken Welten 1.)

Bowden 2010 = Bowden, Hugh: Mystery Cults in the Ancient World. London, 2010 . CIMRM = Vermaseren, Maarten Jozef: Corpus Inscriptionum et Monumentorum Religionis Mithriacae I-II. De Hague, 1956, 1960.

Clauss 1986 = Clauss, Manfred: Mithras und Christus. Historische Zeitschrift 243. (1986), 265-285.

CMRED I = Tudor, Dumitru: Corpus Monumentorum Religionis Equitum Danuviorum (CMRED) I. The Monuments. Leiden, 1969. (Études Préliminaires aux Religions Orientales dans l' empire romain 13.)

CMRED II = Tudor, Dumitru: Corpus Monumentorum Religionis Equitum Danuviorum (CMRED) II. The Analysis and Interpretation of the Monuments. Leiden, 1976. (Études Préliminaires aux Religions Orientales dans l' empire romain 30. ) 
Cribiore 2005 = Cribiore, Rafaela: Gymnastics of the Mind. Greek Education in the Hellenistic and Roman Egypt. Princeton - Oxford, 2005. ${ }^{2}$

Curta 2013 = Curta, Florin: The Elephant in the Room. A Reply to Sebastian Brather. Ephemeris Napocensis 23. (2013), 163-174.

Delehaye 1910 = Delehaye, Hippolyte: Acta Sanctorum Novembris, tomus III. Bruxellis, 1910. 748-784.

Díaz-Andreu et alii 2005 = Díaz-Andreu, Margarita - Lucy, Sam - Babić, Staša Edwards, David N.: The Archaeology of Identity. Approaches to Gender, Age, Status and Religion. London - New York, 2005.

Dinkler-von Schubert 1980 = Dinkler-von Schubert, Erika: Arca und scrinium. Zu Ikonographie und Zweckbestimmung spätrömischer Kästchen, Jahrbuch für Antike und Christentum 23. (1980), 141-157.

Dulaey 1993 = Dulaey, Marcel: Victorin de Poetovio. Premier exégète latin I-II. Paris, 1993. (Collection des Études Augustiniennes, Série Antiquité 140.)

Fitz 1957 = Fitz Jenő: A sárkeszi mithraeum. Székesfehérvár, 1957. (Az István Király Múzeum Közleményei Ser. B 9.)

Fitz 1994 = Fitz Jenő: Die Verwaltung Pannoniens in der Römerzeit III. Budapest, 1994. Gabrieli 1996 = Gabrieli, Gabriella: Das Mithraum am Ufer des Neusiedler Sees. Specimina Nova Dissertationum ex Institutis Historiae Antiquae et Archaeologiae Universitatis Quinqueecclesiensis 12. (1996), 151-158.

Gáspár 1986 = Gáspár Dorottya: Christianity in Roman Pannonia. An evaluation of

Early Christian finds and sites from Hungary. Oxford, 2002. (British Archaeological Reports, International Series 1010.)

Gemeinhardt 2007 = Gemeinhardt, Peter: Das lateinische Christentum und die antike pagane Bildung. Tübingen, 2007.

Gesztelyi 2016 = Gesztelyi Tamás: A Seuso-kincs Meleagros táljának képprogramja. Antik Tanulmányok LX. (2016), 143-157.

Grünewald 1979 = Grünewald, Mathilde: Die Gefäßkeramik des Legionslagers von Carnuntum. Wien, 1979. (Die Römische Limes in Österreich 29.)

Gugl-Kremer 2011 = Gugl, Christian - Kremer, Gabrielle: Das mithräum I „Am Stein”. In: Humer, Franz - Kremer, Gabrielle (Hrsg.): Götterbilder - Menschenbilder. Religion und Kulte in Carnuntum. Ausstellungskatalog Carnuntum, Katalog des Niederösterreichischen Landesmuseums. Wien, 2011. 164-166.

Hahn et alii 2008 = Hahn, Johannes - Emmel, Stephen - Gotter, Ulrich (eds.): From Temple to Church. Destruction and Renewal of Local Cultic Topography in Late Antinquity. Leiden, 2008. (Religions in the Graeco-Roman World 163.) Hahn 2015 = Hahn, Johannes: Public Rituals of Depaganization in Late Antiquity. In: Busine, Aude (ed.): Religious Practices and Christianization of the Late Antique City (4th-7th cent.). Leiden, 2015. 115-140. (Religions in the Graeco-Roman World 182.) 
Huskinson $1974=$ Huskinson, Janet: Pagan Mythological Figures and their Significance in Early Christian Art. Papers of the British School of Rome 62. (1974), 68-97.

IlJug 1978 = Šašel, Anna - Šašel, Jaro: Inscriptiones latinae quae in Iugoslavia inter annos MCMXL-MCMLXX repertae et editae sunt. Ljubljana, 1978. (Situla 19.)

Járdányi-Paulovics 1957 = Járdányi-Paulovics Isván: Nagytétényi kutatások. Budapest, 1957. (Régészeti füzetek 3.)

Jürgasch 2016 = Jürgasch, Thomas: Christians and the Invention of Paganism. In: Salzman, Michele Renee - Sághy Marianne - Lizzi Testa, Rita (eds.): Pagans and Christians in Late Antique Rome. Conflict, Competition, and Coexistence in the Fourth Century. Cambridge, 2016. 115-138.

Kat. Carnuntum 2011 = Humer, Franz - Kremer, Gabrielle (Hrsg.): Götterbilder Menschenbilder. Religion und Kulte in Carnuntum. Ausstellungskatalog Carnuntum, Katalog des Niederösterreichischen Landesmuseums. Wien, 2011.

Kat. Carnuntum 2014 = Humer, Franz - Kremer, Gabrielle - Pollhammer, Ernst Pülz, Andreas (Hrsg.): A.D. 313. - Von Carnuntum zum Christentum. Ausstellung im Archäologischen Museum Carnuntinum, Bad Deutsch-Altenburg März 2013 - Oktober 2016. Bad Vöslau, 2014.

Kiss 2014 = Kiss Péter: Új adatok Savaria vallási életéhez. In: Balázs Péter (szerk.): FIRKÁK III. Fiatal Római Koros Kutatók III. Konferenciakötete. 2008. november 25-27. Szombathely, Savaria Múzeum - 2012. november 15-17. Szombathely, Iseum Savariense. Szombathely, 2014. 27-32.

Kiss 2016 = Kiss Péter: The Mithras Sanctuary in Savaria. Elöadás a Symposium Peregrinum - The Mysteries of Mithras and Other Mystic Cults in the Roman World konferencián Marinóban 2016. június 18-án.

Kocsis 1991 = Kocsis László: Das Haus der tribuni laticlavii aus dem Legionslager vom 2-3. Jh. in Carnuntum. Budapest Régiségei 28. (1991), 152-153.

Koncz-Szilágyi 2017 = Koncz István - Szilágyi Márton: Az identitás régészetének elméleti alapjai (Theoretical Foundations of the Archaeology of Identity). Archaeológiai Értesítő 142. (2017), 193-215.

Kovács 1999 = Kovács Péter: Vicus és castellum kapcsolata az Alsó-pannoniai limes mentén. Piliscsaba, 1999. (Studia Classica Universitatis Catholocae de Petro Pázmány Nominatae Series Historica 1.)

Kovács 2004 = Kovács Péter: The Late Roman Epigraphy in Pannonia (260-582). In: Németh György - Piso, Ioan (eds.): Epigraphica II. Mensa Rotunda epigraphiae dacicae pannoniaeque. Debrecen, 2004, 185-195. (Hungarian Polis Studies 11.)

Kovács 2011 = Kovács Péter (szerk.): Fontes pannoniae antiquae in aetate tetrarcharum I. (A.D. 285-305). Az ókori Pannonia forrásai az első tetrarchia korában (Kr. u. 285-305). Budapest, 2011.

Kremer 2014 = Kremer, Gabrielle: Pagane Kulte der späten Kaiserzeit in Carnuntum. In: Humer, Franz - Kremer, Gabrielle - Pollhammer, Ernst - Pülz, And- 
reas (Hrsg.): A.D. 313. - Von Carnuntum zum Christentum. Ausstellung im Archäologischen Museum Carnuntinum, Bad Deutsch-Altenburg März 2013 - Oktober 2016. Bad Vöslau, 2014. 44-51.

Láng 2016 = Láng Orsolya: Itt a vége, fuss el véle, avagy mi történt az aquincumi polgárvárosban a 4. században? Előadás a Fiatal Római Koros Kutatók X. konferenciáján Pápán 2016. május 15-én.

Lavan-Mulyran 2011 = Lavan, Luke - Mulyran, Michael (eds.): The Archaeology of Late Antique Paganism. Leiden, 2011. (Late Antique Archaeology 7.)

Leppin 2015 = Leppin, Hartmut (Hrsg.): Antike Mythologie in christlichen Kontexten der Spätantike. Berlin - München - Bonn, 2015. (Millenium-Studien zu Kultur und Geschichte des ersten Jahrtausends n. Chr. - Millennium-Studies in the Culture and History oft he first Millennium C. E. 54.)

Mastrocinque 2017 = Mastrocinque, Attilio: The Mysteries of Mithras: a Different Account. Tübingen, 2017. (Orientalische Religionen in der Antike 24.)

Mazur 2008 = Mazur, Zeke: Harmonious opposition (Part I): Pythagorean Themes of Cosmogonic Mediation in the Roman Mysteries of Mithras. In: Szabó Ádám - Vargyas Péter (eds.): Cultus deorum: studia religionum ad historiam Vol. II. De rebus aetatis graecorum et romanorum in memoriam István Tóth. Pécs, 2008. 203-222. (Ókortudományi Dolgozatok 2.)

McMullen 1982 = McMullen, Ramsay: The Epigraphic Habit in the Roman Empire. Journal of American Philology 103. (1982), 233-246.

Müller 2004 = Müller Róbert: Római kori épület Hévíz-Egregyen az Attila utcában (Römerzeitliches Gebäude in Hévíz-Egregy, Attila Straße.). Budapest, 2004. (Régészeti értékeink 10.)

Nagy 2007 = Nagy Levente: Erscheinungsbild und Realität. Menschenopfer, Wahrsagung, Magie, Totenbeschwörung in den Mithras-Mysterien? Acta Classica Debreceniensis 43. (2007), 101-119.

Nagy 2012a = Nagy Levente: Pannóniai városok, mártírok, ereklyék. Négy szenvedéstörténet helyszínei nyomában. Pécs, 2012. (Thesaurus Historiae Ecclesiasticae in Universitate Quinqueecclesiensi 1.)

Nagy 2012b = Nagy Levente: The Short History of Time in the Mysteries of Mithras:

The Order of Chaos, the City of Darkness, and the Iconography of Beginnings. Pantheon 7. (2012), 37-58.

Nagy 2012c = Nagy Levente: Bemerkungen zum ikonografischen Programm des frühchristlichen Kästchenbeschlags von Császár (Ungarn), Mitteilungen zur Christlichen Archäologie 18. (2012), 61-90.

Nagy 2016a = Nagy Levente: Gondolatok Tóth István Pannoniai vallástörténetéröl.

Tóth István: Pannoniai vallástörténet. L'Harmattan, Budapest-Pécs, 2015, 251 oldal. Korall 63. (2016), 158-174. 
Nagy 2016b = Nagy Levente: Myth and Salvation in the Fourth Century: Representations of Hercules in Christian Contexts. In: Salzman, Michele Renee Sághy Marianne - Lizzi Testa, Rita (eds.): Pagans and Christians in Late Antique Rome. Conflict, Competition, and Coexistence in the Fourth Century. Cambridge, 2016. 377-398.

Nagy 2016c = Nagy Levente: Interpretationen frühchristlicher Kunst am Beispiel der pannonischen Kästchenbeschläge: Methodische Probleme und unscharfe Terminologie. In: Bugarski, Ivan - Heinrich-Tamáska Orsolya - Ivanišević, Vujadin - Syrbe, Daniel (Hrsg.): Grenzübergänge: Spätrömisch, frühchristlich, frühbyzantinisch als Kategorien der historisch-archäologischen Forschung an der mittleren Donau = Late Roman, Early Christian, Early Byzantine as Categories in Historical-archaeological research on the Middle Danube. Akten des 27. Internationalen Symposiums der Grundprobleme der frühgeschichtlichen Entwicklung im mittleren Donauraum. Ruma, 4.-7. 11. 2015. Remshalden, 2016. 121-132.

Nagy 2018a = Nagy Levente: Aspects of $4^{\text {th }}$ Century Christian Identity in the Late Roman Province Valeria. In: Nagy Levente: Heiden, Christen und ihre Umwelt: Archaeologische, patristische und kirchengeschichtliche Studien - Pagans, Christians and their Surrounding: Archeological, Patristic and Church Historical Studies. Pécs, 2018. megjelenés alatt. (Thesaurus Historiae Ecclesiasticae in Universitate Quinqueecclesiensi 8. - Specimina Nova Dissertationum ex Institutis Historiae Antiquae et Archaeologiae Universitatis Quinqueecclesiensis Supplementum 13.)

Nagy 2018b = Nagy Levente: Christianisation as Historical Process: Methodological Problems of Interpretation of Historical and Archaeological Sources in 3rd 5th Century Pannonia. In: Nagy Levente: Heiden, Christen und ihre Umwelt: Archaeologische, patristische und kirchengeschichtliche Studien - Pagans, Christians and their Surrounding: Archeological, Patristic and Church Historical Studies. Pécs, 2018. megjelenés alatt. (Thesaurus Historiae Ecclesiasticae in Universitate Quinqueecclesiensi 8. - Specimina Nova Dissertationum ex Institutis Historiae Antiquae et Archaeologiae Universitatis Quinqueecclesiensis Supplementum 13.)

Nagy 1950 = Nagy Tibor: A sárkeszi mithraeum és az aquincumi Mithra-emlékek (Le mithréum de Sárkeszi et les monuments mithriaques d' Aquincum). Budapest Régiségei 15. (1950), 45-120.

Nicholson 1995 = Nicholson, Oliver: The End of Mithraism. Antiquity 69. (1995), 358-362.

Ottományi et alii 2014 = Ottományi Katalin - Mráv Zsolt - Fülöpszky István - Mester Edit: Antik gyökereink. Budaörs múltja a régészeti leletek fényében. Budaörs, $2014^{2}$. 
Piso 2003 = Piso, Ioan: Die Inschriften. In: Jobst, Werner (Hrsg.): Das Heiligtum des Juppiter Optimus Maximus aufd dem Pfaffenberg/Carnuntum. Wien, 2003. (Der Römiche Limes in Österreich 41, Sonderband 1.)

Pülz 2014 = Pülz, Andreas: Frühes Christentum am österreichischen Donaulimes. In: Humer, Franz - Kremer, Gabrielle - Pollhammer, Ernst - Pülz, Andreas (Hrsg.): A.D. 313. - Von Carnuntum zum Christentum. Ausstellung im Archäologischen Museum Carnuntinum, Bad Deutsch-Altenburg März 2013 Oktober 2016. Bad Vöslau, 2014. 52-59.

Radnóti 1946-1948 = Radnóti Aladár: Bronz Mithras-tábla Brigetióból (Le bas relief mithraique de bronze de Brigetio). Archaeológiai Értesítő 3:7-9. (19461948), 137-155.

Rebillard-Rüpke 2015 = Rebillard, Éric - Rüpke, Jörg (eds.): Group Identitiy and Religious Individualism in Late Antiquity. Washington, 2015.

RIU 3 = Barkóczi László - Soproni Sándor (Hrsg.): Die römischen Inschriften Ungarns 3: Brigetio (Ergänzung) und die Limesstrecke am Donauknie. Budapest - Bonn, 1981.

Rüpke 2006 = Rüpke, Jörg: Zeit und Fest. Eine Kulturgeschichte des Kalenders. München, 2006.

Rüpke 2013 = Rüpke, Jörg: Individuals and Networks. In: Bricault, Laurent - Bonnet, Corinne (eds.): Panthée: Religious Transformations in the Graeco-Roman Empire. Leiden - Boston, 2013. 261-277. (Religions in the Graeco-Roman World 177.)

Sauer 1996 = Sauer, Eberhard: The End of Paganism in the North-Western Provinces of the Roman Empire. The Example of the Mithras Cult. Oxford, 1996. (British Archaeological Reports, International Series 634.)

Selem 1980 = Selem, Petar: Les religions orientales dans la Pannonie romaine (Partie en Yougoslavie). Leiden, 1980. (Études Préliminaires aux Religions Orientales dans l' empire romain 85.$)$

Szabó 2012 = Szabó Ádám: A Mithraeumok tájolásának kérdéséhez. Antik Tanulmányok 56. (2012), 125-134.

Szabó 2013 = Szabó Csaba: Micro-regional Manifestations of a Private Cult: The Mithraic Community of Apulum. In: Moga, Iulian (ed.): Angels, Demons and Representations of Afterlife within the Jewish, Pagan and Christian Imagery. Iași, 2013. 43-72. (Antiqua et Mediaevalia. Judaica et Orientalia.)

Szabó 2017 = Szabó Csaba: Párbeszéd Róma isteneivel. A római vallások kutatásának jelenlegi állása és perspektívái. Orpheus Noster 9:2 (2017), 151-163.

Topál 2001 = Topál Judit: Mithras Denkmäler von Aquincum. In: Gojkovič Vomer, Mojca - Kolar, Nataša (eds.): Ptuj v rimskem cesarstvu, mitrajizem in njegova doba: Pokrajinski Muzej Ptuj, mednarodno znastveno srečanje, Ptuj, 11.-15. 
Oktober 1999. = Ptuj im römischen Reich, Mithraskult und seine Zeit. Ptuj, 2001. 269-272. (Archaeologia Poetovionensis 2.)

Topál 2003 = Topál Judit: Ägyptische und orientalische Götter und Kulte. In: Zsidi

Paula (Hrsg.): Forschungen in Aquincum 1969-2002. Budapest, 2003. 274-

283. (Aquincum Nostrum II.2.)

Tóth 2011 = Tóth Endre: Lapidarium Savariense. Savaria feliratos kőemlékei. Szombathely, 2011. (Savaria 34/2.)

Tóth 1971 = Tóth István: A fertőrákosi mithraeum I-II. Soproni Szemle 25. (1971), 214-226., 322-334.

Tóth 1988 = Tóth István: Addenda Pannonica Mithraica (Additions to the work of

M. J. Vermaseren: Corpus Inscriptionum et Monumentum Religionis Mithriacae). Specimina Nova Dissertationum ex Institutis Historiae Antiquae et Archaeologiae Universitatis Quinqueecclesiensis 4. (1988), 17-73.

Tóth 2003 = Tóth István: Mithras Pannonicus. Esszék-essays. Budapest - Pécs, 2003.

(Specimina Nova Dissertationum ex Institutis Historiae Antiquae et Archaeologiae Universitatis Quinqueecclesiensis 17.)

Tóth 2004 = Tóth István: Mithras kultusza és a karácsony Poetovióban (Cult of Mithras and the Christmas in Poetovio). Specimina Nova Dissertationum ex Institutis Historiae Antiquae et Archaeologiae Universitatis Quinqueecclesiensis 18. (2004), 237-244.

Tóth 2006 = Tóth István: Egy mithraikus föpap sírja Pannoniából? Ókor 2006/2. 3-6. Tóth 2015 = Tóth István: Pannoniai vallástörténet. Pécs, 2015. (Ókor-történet-írás 2.) Tóth-Visy 1985 = Tóth István - Visy Zsolt: Das große Kultbild des Mithräums und die Probleme des Mithras-Kultes in Intercisa. Specimina Nova Dissertationum ex Institutis Historiae Antiquae et Archaeologiae Universitatis Quinqueecclesiensis 1. (1985), 37-56.

Vágási 2016 = Vágási Tünde: A Szövetséges Nap. Mithras és Sol kapcsolatának ábrázolása Pannoniában. In: Tóth Orsolya (szerk.): A fény az európai kultúrában és tudományban. Debrecen, 2016. 98-122. (Hereditas Graeco-Latinitatis 3.)

Vomer Gojkovič 2001 = Vomer Gojkovič, Mojca: Petovionski Mitreji. In: Vomer Gojkovič, Mojca - Kolar, Nataša (eds.): Ptuj v rimskem cesarstvu, mitrajizem in njegova doba: Pokrajinski Muzej Ptuj, mednarodno znastveno srečanje, Ptuj, 11.-15. Oktober 1999 = Ptuj im römischen Reich, Mithraskult und seine Zeit. Ptuj, 2001. 105-124. (Archaeologia Poetovionensis 2.)

Vermaseren 1963 = Vermaseren, Maarten Josef: Mithras, the Secret God. New York, 1963.

Versluys 2013 = Versluys, Miguel John: Orientalising Roman Gods. In: Bricault, Laurent - Bonnet, Corinne (eds.): Panthée: Religious transformations in the Graeco-Roman Empire. Leiden - Boston, 2013. 235-259. (Religions in the Graeco-Roman World 177.) 
Visy 2016 = Visy Zsolt: Intercisa feliratai. Pécs, 2016.

Wallraff 2001 = Wallraff, Martin: Christus verus Sol. Sonnenverehrung und Christentum in der Spätantike. Münster, 2001. (Jahrbuch für Antike und Christentum Ergänzungsband 32.)

Zsidi 2002 = Zsidi Paula: Az aquincumi polgárváros ún. Symphorus mithraeumának hitelesítő feltárása (Verifying excavation in the so-called Symphorus mithraeum of the Aquincum Civil Town). Aquincumi Füzetek 8. (2002), 38-48.

Zsidi 2011 = Zsidi Paula: Nagy Tibor és az aquincumi Mithras-kutatás (Tibor Nagy und die Mithras-Forschung von Aquincum). Budapest Régiségei 44. (2011), 20-31. 